Psychology of Language and Communication 2018, Vol. 22, No. 1

\title{
Sciendo
}

DOI: $10.2478 /$ plc-2018-0025

\author{
RUTH A. BERMAN
}

Tel Aviv University, Tel Aviv, Israel

\section{FROM PRE-GRAMMATICALITY TO PROFICIENCY IN L1: ACQUIRING AND DEVELOPING INFINITIVAL USAGE IN HEBREW}

\begin{abstract}
The study traces the developmental route in acquisition and use of infinitives (e.g., $l i$ šon 'to sleep', le-exol 'to-eat', la-asot 'to-do') in Hebrew as a first language, proceeding from the initial, "pre-grammatical" emergence of linguistic forms among toddlers to structure-based knowledge and proficient use of the same devices in adolescence. Analysis involves a varied data-base of L1 oral Hebrew usage in: parent-child interactions of children aged $1 ; 6$ to $3 ; 0$ years; elicited storybook-based narratives of preschoolers; and personal-experience narratives and expository talks of schoolchildren, adolescents, and adults. Findings show that infinitives constitute an interesting test-case for examining the route from initial emergence via acquisition to maturely proficient command of a given subsystem in L1. Infinitival structures in Modern Hebrew, a language with an impoverished system of nonfinite verbs and lacking in auxiliaries of the kind common in Standard Average European, reveal a long developmental path, showing increasing complexity at all levels of language use: morphological form, types of syntactic constructions, semantic content, and discursive function, the latter primarily for the purpose of achieving textual connectivity.
\end{abstract}

Key words: L1 aquisition, infinitives, Hebrew

\section{The verb system of Modern Hebrew}

Modern Hebrew (MH) may be best characterized as "a Tense (Mood/ Aspect) language" due to the lack of grammatical marking of mood and aspect (Berman, 2014), although this view runs counter to certain other interpretations of the system (e.g., Dekel, 2010; Kalev, 2017a, 2017b). The present study analyzes the language as distinguishing five categories of tense

Address for correspondence: Ruth A. Berman, Department of Linguistics, Webb 408, Tel Aviv University, Ramat Aviv, 69978 Tel Aviv, Israel. E-mail: rberman@post.tau.ac.il 
and mood that are grammatically marked in $\mathrm{MH}$. These are illustrated in Table 1 for four verbs: rakad 'dance', gadel 'grow', yaca 'go-out, exit', and $b a$ 'come'. Two of these are based on the full or strong consonantal roots $r-q-d$ 'dance' and $g-d-l$ 'grow' compared with two weak or defective roots with historical ?, $\subseteq, h$ - the so-called "gutturals" represented by the letters alef, ayin, and heh respectively or the glides $w, y$, represented here by the motion verbs $y$-c-? 'go-out, exit' and $b$ - $w$-? 'come' (Ravid, 2003; Schwarzwald, 2003; Seroussi, 2014). The four verbs in Table 1 represent three of the seven morphological patterns or prosodic templates (termed binyan constructions), in which verbs are typically in active rather than passive or middle voice (Berman, 1993; Ravid et al., 2016).

Table 1. Tense/Mood categories of Modern Hebrew [Infinitive, Imperative, Present, Past, and Future], with verbs based on both full and defective consonantal roots in three non-middle, non-passive binyan patterns

\begin{tabular}{|c|c|c|c|c|c|c|c|}
\hline binyan & Root & Gloss & $\begin{array}{c}\text { Inf. } \\
\text { [-Tns] }\end{array}$ & $\underset{[+ \text { Imp }}{[+ \text { Mood] }}$ & $\begin{array}{c}\text { Present } \\
{\left[\begin{array}{ll}0 & \text { Tns] }\end{array}\right.}\end{array}$ & $\begin{array}{c}\text { Past } \\
{[+ \text { Tns] }}\end{array}$ & $\begin{array}{l}\text { Future } \\
\text { [+Tns] }\end{array}$ \\
\hline \multirow{4}{*}{$\begin{array}{l}\mathrm{P} 1 \\
p a a^{\prime} a l\end{array}$} & r-q-d & dance, Intransitive & li-rkod & rekod & roked & rakad & yi-rkod \\
\hline & g-d-1 & grow, Intransitive & $l i-g d o l$ & gdal & godel & gadal & $y i-g d a l$ \\
\hline & $y-c-{ }^{6}$ & go out & la-cet & ce & yoce & yaca & ye-ce \\
\hline & b-w-' & come & la-vo & bo & $b a$ & $b a$ & $y a-v o$ \\
\hline \multirow{4}{*}{$\begin{array}{l}\mathrm{P} 3 \\
\text { pi'el }\end{array}$} & $r-q-d$ & skip & le-raked & raked & me-raked & riked & ye-raked \\
\hline & g-d-1 & raise & le-gadel & gadel & me-gadel & gidel & ye-gadel \\
\hline & y-c-' & export & le-yace & yace & me-yace & yice & ye-yace \\
\hline & b-w-' & import & le-yave & yave & me-yave & yive & ye-yave \\
\hline \multirow{4}{*}{$\begin{array}{l}\text { P5 } \\
\text { hif' } i l\end{array}$} & r-q-d & make-dance & le-harkid & harked & ma-rkid & hi-rkid & ya-rkid \\
\hline & g-d-1 & enlarge & le-hagdil & hagdel & ma-gdil & hi-gdil & $y a-g d i l$ \\
\hline & $y-c-{ }^{6}$ & take out & le-hoci & hoce & $m o-c i$ & ho-ci & $y o-c i$ \\
\hline & b-w-' & bring & le-havi & have & $m e-v i$ & $h e-v i$ & $y a-v i$ \\
\hline
\end{tabular}

Table 1 shows that Hebrew-speaking children need to master a wide range of different forms in constructing verbs in their language, including mood/ tense distinctions in different binyan prosodic templates. The latter also involve valence and voice alternations between transitive and intransitive verbs and between active, passive, and middle voice. For example, the verb root $g-d-l$ occurs in the intransitive verb gadal with a change-of-state sense 'grow, get bigger' and middle voice hitgadel 'aggrandize oneself'. The same root also occurs in the transitive verbs gidel 'grow (crops), raise (children)' and causative higdil 'make bigger, enlarge', and in their passive-voice alternatives gudal 'be raised', hugdal 'be enlarged' (Berman, 1993). Besides, in addition

\footnotetext{
${ }^{1}$ Since Hebrew verbs have no "basic" or unmarked form like English, e.g. dance, grow, go-out, come, the convention used here for a citation form is the morphologically simple form of past tense, $3^{\text {rd }}$ person, masculine singular.
} 
to the forms illustrated in Table 1, speakers need to mark each verb except for Infinitives by the inflectional categories of: Number (Singular/Plural), Gender (Masculine/Feminine), and Person $-2^{\text {nd }}$ person in Imperatives, and $1^{\text {st }}, 2^{\text {nd }}$, and $3^{\text {rd }}$ person in Past and Future tense. The special case of Present or "Zero Tense" forms are noted further below ${ }^{2}$.

This large variety of forms takes children several years to master (Lustigman, 2013, 2016b), yet the system is relatively impoverished in terms of grammatically marked temporal distinctions. In contrast to classical Biblical Hebrew, Modern Hebrew has no grammatized means for encoding the categories of mood or aspect ${ }^{3}$. Moreover, while it has three nonfinite verb forms - participles, gerunds, and infinitives - the former two categories are highly restricted, occurring mainly in elevated or literary usage (Berman 2017). The so-called benoni 'intermediate' forms serve as non-finite participles both in (1) small clausecomplements and (2) in adverbial circumstantial clauses as well as (3) as Present Tense alternating with Past and Future tense reference. In the latter capacity, they are characterized as zero tense in Table 1 since, unlike past and future verbs, they are not marked for Person (see Berman, 1978a, pp. 175-179). The other nonfinite verb form, the gerund or šem pó 'al natuy 'name (of) noun inflected = inflected verbal noun', is highly restricted semantically and syntactically, and is rare in spoken Hebrew usage (Berman, 1978a, pp. 282-317). ${ }^{4}$ As such it is largely irrelevant to child language

This state of affairs has two main consequences for Modern Hebrew structure and use. First, all five of the categories listed in Table 1, including infinitives, serve multiple functions (Berman, 2014); second, infinitives the target form of this study - have become the most pervasive and least restricted category of non-finite verbs in the language, at all levels of usage.

\footnotetext{
2 Part of the task for young children in mastering the Hebrew verb system is well articulated in the following excerpt from Ravid et al. (2016, p. 100): "For example, the verb meaning 'knit' from the root $s-r$ - $g$ is inserted into three temporal paradigms in the pa'al binyan pattern, thus: Past Tense $\mathrm{CaCaC}>\mathrm{sarag}$, Present Tense $\mathrm{CoCeC}>$ soreg, and $\mathrm{PiCCoC}$ [where P stands for Prefix ] > Future yisrog, Imperative tisrog, Infinitive lisrog (where P stands for the temporal-marking prefix); while the verb meaning 'go/come-in, enter' is constructed from the root $k-n-s$ inserted into two temporal paradigms in the nif'al pattern as follows: Past and Present Tense niCCaC > nixnas and PiCaCeC > Future yikanes, Imperative hikanes, Infinitive lehikanes" (2016, p. 100). Note, however, that in addition to these alternations, each verb needs to be inflected for Number, Gender and, in many instances, for Person.

${ }^{3}$ The only exception is marked by the construction haya + Verb, where haya 'was' is the past tense form of the copular verb li-hyot 'to be' and the verb that follows is in the benoni participial form, standing for (nonobligatorily marked) habitual past tense, e.g., hay-inu holx-im la-yam kal šabat 'be:PAST-1PL go: PRS-M.PL' = 'we would $\sim$ used to go to the beach every Saturday' (Berman, 1980, 2001).

${ }^{4}$ The gerund is traditionally termed "inflected infinitive" because it is typically attached to one of the four basic prepositions be- 'in, at', ke- 'like, as', me- 'from, of' as well as le- 'to', the latter in the case of the Infinitive, compare bi-r'ot-o 'in $\sim$ on seeing-his $=$ on his seeing' where the suffixed pronoun refers to the sentential subject, versus li-r'ot-o 'to-see-him', where the same suffix stands for the direct object of the same verb 'to see'. That is, infinitives of transitive verbs taking direct objects can take accusative pronouns as an inflection. Compare: li-r'oto with analytical li-r'ot oto both meaning 'to-see him'. The bound accusative morpheme is highly restricted and largely irrelevant to child language (Kaplan and Berman, 2015).
} 


\section{The target form: Hebrew Infinitives}

Reference here is to the Hebrew equivalents of what are termed "infinitives" in Standard Average European (SAE), as illustrated for different languages in (1):

(1) a. English: to talk, to sleep, to eat

b. German: reden, schlafen, essen

c. Spanish: hablar, dormir, comer

d. Polish: mówić, spać, jeść

As a language with relatively sparse verb inflection, English (1a) uses the analytic device of preposing the directional and dative preposition 'to' to the uninflected stem or basic form of a verb. German, also a Germanic language, uses an invariant suffix for this purpose, adding the ending -en to the verb stem (and see, too, Dutch praten, slapen, eten). Spanish, like French and other Romance languages, adds one of three suffixes to the verb stem, in this case $-a r,-i r$, -er respectively, indicating the three different conjugations affecting how the verbs in each are inflected. Polish, the language of Barbara Bokus, also adds a suffix, usually in the form of $-\dot{c}$ as (1d), or $-c$ when following a vowel (e.g., biec 'to run', móc 'to be able') 5 .

Hebrew, as a highly inflected (typically suffixing) language, marks the infinitive (termed traditionally šem ha-póal "name (of) the-verb = the verbal noun') by means of an invariant prefixal $l$-. Like its English equivalent 'to', it takes the same form as the preposition specifying a directional goal and also dative case. However, unlike in the other languages listed in (1), the sonorant $l$ is followed by a vowel that alternates in relation to the morpho-phonological properties of the initial stem element (for example, ladaber, 'to talk', lišon 'to sleep', le'exol 'to eat'). One such vowel alternation corresponds in a sense to the conjugations of Romance languages, being dependent on the binyan morphological pattern (prosodic template) to which the verb belongs (see description in relation to Table 1 above) ${ }^{6}$. Such alternations are shown in Table 2.

The forms in Table 2 show that the least marked form of the vowel following infinitival $l$ - is the historical schwa. This is pronounced in current Hebrew as $e$, alternating with the high vowel $-i$ - in the basic and most common pattern pa'al. Two other morpho-phonological factors are (i) the occurrence of a historical "guttural" as the root initial consonant (Table 3) and (ii) the distinction between full verb-roots like those in Tables 1 and 2 compared with verbs with weak or defective roots as in Table 4.

\footnotetext{
${ }^{5}$ I am indebted to Anetta Kopeska for information on Polish, any inadequacies in this presentation are mine alone.

${ }^{6}$ The two strictly passive, hence inflectionally derived, binyan patterns - pu'al and huf'al, the passive alternations of largely transitive $p i$ ' $e l$ and ' $h i f$ ' $i l$ respectively - have no infinitive forms at all.
} 
Table 2. Infinitive forms of verbs in different binyan patterns for the two verb roots $g-d-l$ 'grow', $k$ - $t-b$ 'write'

\begin{tabular}{lll}
\hline binyan pattern & Root g-d-l Infinitive + Gloss & Root $\boldsymbol{k}$-t-b Infinitive + Gloss \\
\hline pa'al [Basic]: & ligdol 'to grow-INTR & lixtov 'to-write' \\
pi'el [Active]: & lagadel 'to-raise, grow-TRANS' & laxatev 'to-address, to cc' \\
hif'il [Causative]: & lahagdil 'to-enlarge' & lahaxtiv 'to-dictate' \\
hitpa'el [Middle]: & lahitgadel 'to-aggrandize (oneself)' & lahitkatev 'to-correspond' \\
\hline
\end{tabular}

'Note: The verb root $r-q-d$ 'dance' in Table 1 is replaced here by $k-t-b$ 'write' as a root from which established verbs are derived from four different binyan patterns. Alternations between the historical stop $b$ and the spirant $v$ in the latter are due to morphophonological constraints that today are largely lexically defined.

Table 3. Infinitive forms of verbs with root-initial historical gutturals (in the $\mathrm{pa}^{\prime}$ 'al pattern)

\begin{tabular}{|c|c|c|c|}
\hline Root-initial guttural & Letter & $\begin{array}{l}\text { Historical Root: } \\
\text { Infinitive + Gloss }\end{array}$ & $\begin{array}{l}\text { Historical Root: } \\
\text { Infinitive + Gloss }\end{array}$ \\
\hline $\begin{array}{l}\text { voiced pharyngeal } \\
\text { fricative } \varsigma\end{array}$ & ayin & $\varsigma-b-d$ : la'avod 'to-work'ii & 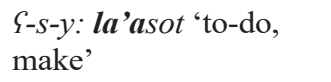 \\
\hline $\begin{array}{l}\text { voiceless pharyngeal } \\
\text { fricative } \hbar\end{array}$ & chet & $\hbar-\check{s}-b$ : laxšov 'to think' & $\begin{array}{l}\hbar \text {-t-m: laxlom } \\
\text { 'to-dream' }\end{array}$ \\
\hline voiced glottal fricative $h$ & he & $h-p-k$ : lahafox 'to-turn over' & h-r-g: laharog 'to kill' \\
\hline voiceless glottal stop? & alef & P-k-l: le'exol 'to-eat' & P-s-p: le'esof 'to collect' \\
\hline
\end{tabular}

The forms in Table 3 show that the historical gutturals - although, as noted, not distinguished phonetically in most current Hebrew speech - still have the effect of lowering the vowel following infinitival $l$ - to $a$ compared with the high or mid vowels $i$ and schwa in Table 2. This trend is so strong that even educated adult speakers today lower the required $e$ after root-initial alef to $a$ (except in the case of high-frequency verbs like leexol 'to-eat'). In everyday usage, it is common to hear laasof 'to collect', laaroz 'to pack', laamod 'to estimate' with verbs beginning with historical (and orthographic) alef treated as though they began with ayin.

Another factor affecting the choice of infinitival vowel is with irregular verbs, that is, ones based on defective or "weak" roots in which one or more of the root elements is elided in some words based on them. Occurrence of these elements - guttural ayin, alef, he, the glides $y, w$, and sometimes the nasal $n$-have an effect on how Infinitives are pronounced, as in the examples in Table 4. These typically deviate from the regular or canonic form $\mathrm{li}-\mathrm{CCoC}$ of infinitives in the pa'al conjugation, as shown in the first line of Table 1 and in the second column of Table 4 below. 
Table 4. Infinitive forms of irregular verbs based on defective roots compared with regular or strong verbs, in the $p a$ 'al pattern

\begin{tabular}{lllll}
\hline Root & Irregular Infinitive & Gloss & Regular Infinitive & Gloss \\
\hline$y-\check{s}-b$ & la-šévet & 'to-sit (down)' & li-šbor & 'to-break' \\
$h-l-k$ & $l a-l e ́ x e t$ & 'to-go, walk' & $l i-l m o d$ & 'to-learn, study' \\
$z-w-z$ & $l a-z u z$ & 'to-move' & $l i-z r o k$ & 'to-throw (away)' \\
$s-y-m$ & $l a-s i m$ & 'to-put' & $l i-s p o r$ & 'to-count' \\
$n-g-\varsigma$ & $l a-g a ́ a t$ & 'to-touch' & $l i-g m o r$ & 'to-finish' \\
$n-t-n$ & $l a-t e t$ & 'to-take' & $l i-n s ̌ o m$ & 'to-breathe' \\
\hline
\end{tabular}

Interestingly, once children begin using the infinitval le- marker, they no longer make any errors in its form, but follow adult usage across the different verbs. Note, further, that in all cases listed in Tables 2 through 4, the stem of the Infinitive is the same as the stem of verbs in the Imperative and in Future tense. This reflects the fact that like Hebrew infinitives, like their counterparts in other languages, express irrealis mood. That is, they relate to events that are not known to have happened or states of affairs that do not exist at the time of speaking (or writing), referring to possible rather than realized worlds. In Hebrew this is morphologically evidenced by the dative $l$ - prefix, which points to goal orientation. Unlike the four other categories of tense and mood shown in Table 1, Infinitives are not inflected for number, gender, or person. As a result, they are morphologically invariant, in all instances marked by an initial $l$ - (occasionally taking a bound accusative pronoun, see fn. 4 above). The only alternation they allow is phonological, with the vowel that follows affected by the verb-root between basic $i$ or $e$ (in place of normative $s c h w a$ ) or lowered to $a$ in certain environments.

In sum, as the focus of this study, Infinitives differ from other verb forms in the language since they are basically invariant in morphological form. On the other hand, they constitute the major non-finite form of verbs in Modern Hebrew occurring, as we show below, in varied syntactic environments, fulfilling multiple roles in discourse, and manifesting pervasive occurrence at all levels and in all types of usage.

\section{The Study}

The findings discussed below derive from a large and varied oral data-base of Modern Hebrew used by native speakers in a variety of communicative contexts, at various age-groups from early childhood to adulthood. The data base consists of five main corpora, as detailed in Table 5 . 


\begin{tabular}{|c|c|c|c|c|}
\hline Elicitation Type & Target Population & \multicolumn{2}{|c|}{ Participants } & References \\
\hline Materials & $\begin{array}{l}\text { Communicative } \\
\text { Setting }\end{array}$ & No. & Age/schooling & \\
\hline $\begin{array}{l}\text { Longitudinal } \\
\text { Weekly recorded } \\
\text { recorded }\end{array}$ & $\begin{array}{l}\text { Toddlers: } \\
\text { Conversational } \\
\text { Interchanges } \\
\text { with caretakers }\end{array}$ & $\begin{array}{l}4 \\
3 \text { girls, } \\
1 \text { boy }\end{array}$ & $\begin{array}{l}1 ; 6-3 ; 0 \\
\text { Home or } \\
\text { infant school }\end{array}$ & $\begin{array}{l}\text { Lustigman, 2012, } \\
2013\end{array}$ \\
\hline $\begin{array}{l}\text { Cross-sectional } \\
\text { Individual } \\
\text { one-hour } \\
\text { sessions }\end{array}$ & $\begin{array}{l}\text { Preschoolers: } \\
\text { Interview } \\
\text { between } \\
\text { investigator } \\
\text { and child }\end{array}$ & $\begin{array}{l}100 \\
\text { (20 per } \\
\text { age- } \\
\text { group) }\end{array}$ & $\begin{array}{l}1 ; 6-1 ; 11 \\
2 ; 0-2 ; 11 \\
3 ; 0-3 ; 11 \\
4 ; 0-4 ; 11 \\
5 ; 0-5 ; 6\end{array}$ & $\begin{array}{l}\text { Dromi \& Berman, } \\
1986\end{array}$ \\
\hline $\begin{array}{l}\text { "Frog story" } \\
\text { 15-page picture } \\
\text { storybook }\end{array}$ & $\begin{array}{l}\text { Preschool }> \\
\text { Adults }\end{array}$ & $\begin{array}{l}60 \\
(12 \text { per } \\
\text { age- } \\
\text { group })\end{array}$ & $\begin{array}{l}\text { 3-4 years } \\
4-5 \text { years } \\
5-6 \text { years } \\
9-10 \text { years } \\
\text { Adults }\end{array}$ & $\begin{array}{l}\text { Berman, } 1988 \\
\text { Berman \& Neeman, } \\
1994\end{array}$ \\
\hline $\begin{array}{l}\text { "Fight story" } \\
\text { narratives }\end{array}$ & $\begin{array}{l}\text { Preschoolers, } \\
\text { early school-age: } \\
\text { Individual } \\
\text { elicitation } \\
\text { by researcher }\end{array}$ & $\begin{array}{l}36 \\
(12 \text { per } \\
\text { age- } \\
\text { Group) }\end{array}$ & $\begin{array}{l}3-4 \text { years } \\
5-6 \text { years } \\
7-8 \text { years }\end{array}$ & Berman, 2004b \\
\hline $\begin{array}{l}\text { "Interpersonal } \\
\text { Conflict": } \\
\text { Film clip } \\
\text { showing } \\
\text { scenes of conflict } \\
\text { a) Personal- } \\
\text { experience } \\
\text { narratives + } \\
\text { b) Expository } \\
\text { talks }\end{array}$ & $\begin{array}{l}\text { Later language } \\
\text { Development: } \\
9-10 \text { years } \\
\text { gradeschool } \\
12-13 \text { middle } \\
\text { school } \\
16-17 \text { high } \\
\text { school } \\
20-30 \text { univ } \\
\text { graduates }\end{array}$ & $\begin{array}{l}80 \\
(20 \text { per } \\
\text { age- } \\
\text { group) }\end{array}$ & & $\begin{array}{l}\text { Berman \& } \\
\text { Verhoeven, } 2002 \\
\text { Berman, } 2008\end{array}$ \\
\hline
\end{tabular}

Participants were native Hebrew-speaking children and adolescents of middle-to-high SES background, with adults all university-educated, but non-expert speaker-writers (that is, excluding authors, journalists, Hebrew language specialists and teachers, etc.). Israeli children typically go to nursery school from age two years, kindergarten from age 5, with school-based reading and writing activities officially starting from 1st grade, age 6 to 7 years.

Given the wide variety of age-ranges, elicitation methods, communicative settings and discourse genres of our data-base, the findings described in Section 4 delineate general trends in the distribution, structure, and use of infinitival constructions. That is, they present general developmental and discursive trends rather than statistical breakdowns. Relevant data on some of these analyses are available in the references in the last column of Table 5 and in research studies referred to below. 


\section{Results: Developmental Phases in Acquisition and Use of Infinitives}

Findings from the data-base summarized in Table 5 are described below in terms of different stages of age/schooling development combined with different levels of structural complexity and discursive function, as follows: Form and function of infinitives in isolation (Section 4.1); infinitives as a means of verb-phrase expansion (Section 4.2); infinitives in clause-combining complex syntax (Section 4.3); and in clause-packing discourse connectivity (Section 4.4).

\subsection{Form and function of infinitives in isolation}

This section concerns early verb forms from so-called "bare stems" to conventional $l$ - marking (4.1.1) and describes how infinitives are used by toddlers and young pre-school children and their adult interlocutors as an informal type of Imperative (4.1.2).

4.1.1. Unmarked bare verb stems. As can be seen in Table 1, Hebrew has no uninflected "basic" or simplex form of verbs like, say, English talk, sleep, eat (Berman, 1978b). Instead, children initially resort to use of "bare stems" of the kind illustrated in Table 6.

Table 6. "Bare stem" forms observed in early "pre-grammatical" child usage of verbs in three different binyan patterns, interpretable in isolation as Infinitives or as inflected forms

\begin{tabular}{|c|c|c|c|c|c|}
\hline Bare stem & binyan & Infinitive & & r Possible Interpret & ations \\
\hline gor 'close' & $p a^{\prime} a l$ & $p a^{\prime} a l$ & $\begin{array}{l}\text { ti-sgor! } \\
\text { Imperative } \\
\text { M.SG }\end{array}$ & $\begin{array}{l}\text { yi-sgor } \\
\text { Future } 1^{\text {st }}, 3 \text { rd SG. }\end{array}$ & $\begin{array}{l}\text { ni-sgor } \\
\text { Future } 1^{\text {st }} \text { PL. }\end{array}$ \\
\hline ber 'talk' & pi'el & pi'el & $\begin{array}{l}\text { me-daber } \\
\text { Present }\end{array}$ & $\begin{array}{l}\text { ye-daber } \\
\text { Future } 1^{\text {st }}, 3^{\text {rd }} \text { SG. }\end{array}$ & $\begin{array}{l}\text { diber } \\
\text { Past } 3^{\text {rd }}, \text { M.SG. }\end{array}$ \\
\hline zir 'put back' & hif'il & hif'il & $\begin{array}{l}\text { ta-xzir! } \\
\text { Imperative } \\
\text { M.SG }\end{array}$ & $\begin{array}{l}\text { hi-xzir } \\
\text { Past } 3^{\text {rd }} \text {, M.SG. }\end{array}$ & \\
\hline
\end{tabular}

As discussed from various points of view in the research on early verb use in Hebrew, such forms are a robust phenomenon, constituting the bulk of children's initial verb forms between ages of around 1;6 to 2;0 (e.g., Adam \& Bat-El, 2008; Berman \& Armon-Lotem, 1997; Lustigman, 2012). As indicated in the examples in (2), these are typically "opaque", since they lack a clear target form and need to be interpreted by adults in relation to their use in a particular linguistic or extra-linguistic context (Lustigman, 2015). Moreover, they are typically "juvenile" in the sense that they are confined to child language, and do not represent any conventional form of a Hebrew verb in established usage (Berman, 1981; Ravid, 1995). In other words, they represent what I have elsewhere termed "pre-grammatical" use of language 
(Berman, 1986, 2004a). Importantly, they represent Hebrew-speaking children's original and innovative, yet shared, way of breaking into the complex system of verb-inflection in the target language. Besides, while they are morphologically opaque, these "bare stems' are phonologically well-formed, representing possible strings in Hebrew, and marking the particular binyan membership of the verb they represent ${ }^{7}$.

As such, bare-stem forms are also transient, being replaced early on by a conventionally marked form of the verb in question, usually a present-tense form or an Infinitive (Lustigman, 2013, 2016a).

4.1.2. Form and functions of early infinitives. Interestingly enough, once children abandon reliance on bare stems, adding infinitival $l$-, to the infinitive forms that they use, they do not make non-adultlike errors in producing such forms, even though these involved complex morphophonological alternations (see Tables 2 to 4 above). This is evident in the examples in (2), from toddlers between the ages of $1 ; 9$ to $2 ; 3$.

(2) a. ima, la-rédet 'Mommy, (I want) to-get down' [cf. earlier éde! ]

b. li-xtov po! 'to-write here = write here!'

c. li-r'ot, li-r'ot, li-r'ot ta séfer! 'to-see [x3] the-book!'

d. le-saper li gamad katan 'to-tell me (the story of) little dwarf'

e. la-sim kan? 'to-put (it down) here? = should I ...?'

f. lo li-pol! 'not to-fall = don't fall' [to his teddy] '

The examples in (2), from four different children, demonstrate that structurally, the $l V$ - infinitival marker is correctly formed in each case. In function, all these examples represent some form of Imperative mood, expressing requests and demands from child to adult. While these are not the regular inflected form of Imperative verbs (see Table 1 above), they are common in everyday colloquial speech, most particularly that addressed by parents and nursery-school teachers to young children, This is illustrated by examples of child-directed speech in (3) and (4).

(3) a. axšav li-šon 'now (it's time to go) to sleep'

b. le-exol yafe! 'to-eat nicely = don't mess'

c. lo li-c'ok! 'not to-shout = don't shout'

(4) Mother:

ma la-asot la-nadneda?

'What to-do (= should I do) to the swing?'

Rotem $[2 ; 1]:$ lator $=$ la-acor 'stop (it)'

\footnotetext{
7 They cannot be attributed to articulatory difficulty with bi- or even poly-syllabic forms in their language, since at the same age children do produce forms like óto for 'car', afefon for melafefon 'cucumber', sasuim for tsa'atsu'im 'toys'.

${ }^{8}$ English-speaking children at this developmental stage would say 'down!', using the particle indicating direction of movement, displaying the clear typological difference between Hebrew as a "verb-framed" language compared with the verb "satellites" marking direction in a language like English (Slobin, 2004).
} 
In sum, early Infinitives, which emerge around age 2 years, are morphologically well-formed, syntactically as independent or isolated predicating entities in a single clause, and discursively they function in both child speech input and output as an alternative to the inflected form of verbs in Imperative mood or Future tense (Berman, 1985). ${ }^{9}$

The rest of the findings described in Section 4 concern infinitival forms that do not occur in syntactic isolation. Rather, they are contingent on some other construction, where "contingency" means that a given construction is dependent on another for grammatical well-formedness and/or for semantic interpretation, at different levels, as follows: (i) within-clause modifying elements that serve as "triggers" for infinitival forms - e.g., 'need to walk', 'start to walk' (§4.2); (ii) clause-combining complex syntax, where two or more predications are coordinated - e.g., 'walked and talked', 'came, saw, and conquered' (\$4.3); and (iii) syntactic packaging involving strings of infinitives combined to achieve textual connective (\$4.4).

\section{2. "Extended predicates": Infinitives as a means of verb-phrase expansion}

The first type of expansion in use of infinitives that are syntactically contingent on a preceding lexico-syntactic element is in constructions termed nasu murxav 'predicate predicate widened = extended predicate' in Hebrew language studies. In these constructions, a tensed verb or predicative operator is followed by an infinitive or participle. For example, Azar (1977) and Blau (1966) note instances such as modal carix la-léxet 'must $\sim$ has to-go', asuy la-léxet 'is-likely to go'. Termed variously in child language and general linguistics "predicate complement constructions" (Bloom, Tackeff, \& Lahey, 1984), "complement taking verbs" (Diessel, 2004), or "complex VPs" (Givón, 2009), these constructions emerge early in Hebrew. This is illustrated in the examples in (5) from two-year-old children. ${ }^{10}$

(5) a. roca le-cayer et ha-kélev 'want:F ACC the-dog = I want to-draw the dog'

b. lo yexola le-saper lax 'not can:F to-tell to-you = I don't know how to tell you (the story)'

c. lo gamarti le-exol 'not finish: 1STSG to-eat = I haven't finished eating'

d. hu lo ohev le-saxek iti 'he not like to-play with-me = he doesn't like playing with me'

\footnotetext{
${ }_{9}$ In adult usage, clauses with infinitives may also serve in isolation, replacing tense-marked subordinate clauses in a diachronic shift or type of discursive reduction of main clauses in the process of insubordination" (Evans, 2007; Evans \& Watanabe, 2016). These, however, are typical of spoken interactions of the type confined to toddlers in our data-base.

${ }^{10}$ For ease of presentation, children's articulation is corrected to adultlike in these examples, e.g., (3a) the child said le-saye for le-cayer 'to-draw', in (3c) lexol instead of le'exol 'to eat', on condition that the 1- infinitive marker was clearly present.
} 
These constructions are of critical importance in Hebrew grammar and usage, as a means of elaborating on the verbal element in a language lacking in auxiliaries (Berman, 1980). They are analyzed here, following Berman \& Slobin (1994, pp. 660-662), as "clause-internal', since the initial, tensed element that serves to "trigger" the infinitive does not represent a distinct situation but merely serves to modify the infinitival.

Developmentally, children start out by extensive use of the verb roce roca 'want:M F' followed by other common modal verbs like yaxol 'can, be able', carix 'must, have to'; these are followed by aspectual markers like hitxil 'begin, start', himšix 'go on, continue'; and later to develop are attitudinal or evaluative terms like those meaning 'like, enjoy'. Child directed speech (CDS) typically includes a more extended, richer repertoire of such expressions, as in the excerpts in (6) from a mother talking to her 20-month old daughter:

(6) a. asur li-mroax et ha-pomelit al ha-šulxan

'(it is) forbidden to-smear ACC the grapefruit on the-table = you're not allowed to ...'

b. et ze i-efšar ki eyn po xor, efšar le-hašxil rak be-dvarim še-yěs bahem xor mi-shney ha-cdadim ACC

'it non-possible because not here hole, possible to-thread only inthings that have (a) hole on both sides' = 'it's (im)possible = you can ('t)'

Moreover, adult input also uses the basic triggers in a range of inflected forms, for example, raci-nu 'want.PST-1ST.PL 'we-wanted', $t$-uxl-i 'FUT. $2^{\mathrm{ND}}$-can- $2^{\mathrm{ND}} . \mathrm{F}=$ you'll be able to'. This constrasts with their children's invariant (except for gender-dependent self-reference) roce $\sim$ roca '(I) want. $\mathrm{M} \sim \mathrm{F}$ ', yaxol $\sim$ yexol-a '(I) can.M F.'

In addition to differences between the usage of toddlers and their caretakers, older speakers in general use a far wider range of lexical items, including terms in more formal register. This is, as shown in excerpt (7) from adults' oral personal-experience narratives and discussions of interpersonal conflict, by semantic class of "trigger".

(7) Modal: $\quad$ efšar le-taken '(it's) possible to-fix' hayiti amura la'avod 'I-was supposed to-work' aléxa li-lmod '(it's incumbent) upon you to-learn' nitan lir'ot '(it's) given to-see = one can see'

Aspectual: notim la-riv '(they) tend to-quarrel'

hispiku le-sakem '(they) managed = had-time tosummarize'

naclíax le-sader 'we'll-manage = succeed to-arrange' 
Attitudinal: adif la'asot '(it's) preferable to-do ...'

na'im le-hizaxer '(it's) nice to-remember'

naxon yoter le-hitpašer '(it's) better to-compromise'

Semantically, as noted, children typically rely mainly on deontic rather than epistemic modals, in keeping with more general cognitive developmental trends (Reilly, Jisa, Baruch \& Berman, 2002). This is consistent with what de Villiers and de Villiers (1986) point out for English. They note that all of the young children's utterances containing V-to-V constructions occurred regularly with "particular matrix verbs", initially, ones that "appear to function as modal verbs", such as I wanna open it, I gonna get it, and only later with nonmodal matrix verbs such as try, like. Along similar lines, studying a different group of English-acquiring children, Diessel (2004, p. 63) lists as the following as the most frequent "complement taking verbs": wanna, hafta, like, gotta, try, be hard, stop, need, start, know.

Another development in use of such constructions is by stringing of infinitives, as in the examples from children between ages 2;6 and 3;0 years in (8) below. (Thefirst example is the formulaic routine for 'go to sleep').

(8) a. lo roce la-lexet li-šon '(I) don't want to-go to-sleep

b. ani lo yaxol la-azor lexa 'I not can to-help to-you = I can't help you'

c. hu yodea le-lamed le-saxek 'he knows (how) to teach to-play ${ }^{11}$

Syntactically, modal and other verbal operators occurring in extended predicate constructions constitute precursors to clause-combining operations in general. That is, they occur prior to matrix verbs that take tense-marked sentential complements (Lustigman \& Berman, 2016). This is in line with Givón's (2009, pp. 129-203) discussion of the acquisition of two types of "complex clauses", with V-complements acquired earlier (ca. age 1;8 - 2;9) than other subordinated clauses (around ages three to five years). And it is compatible with the findings of the Hebrew-based cross-sectional study of Dromi and Berman (1986), who observed "a gradual rise in the use of more than one verb in the same clause: Around 3\% of all clauses at age 2, as against some $6 \%$ at age 5 are 'expanded VPs' in which modal and aspectual verbs are used together with an infinitival subjectless complement".

\subsection{Clause-Combining Infinitival Constructions}

A critical role that emerges for infinitives in Hebrew is in combining two or more non-finite clauses, where each clause represents a distinct predication, referring to a different event, activity or state than the one(s) preceding it.

${ }_{11}$ Another such construction is highly formulaic and confined to formal usage, with a tensed verb separated from its infinitival complement by the coordinating conjunction ve- 'and' as in halax ve-gadal "went and grew' $=$ ' got bigger and bigger, increasingly'. 
4.3.1. Infinitival Complement and Adverbial Clauses. A construction lying between the clause-internal extended predicates of Section 4.2 and combining of separate clauses discussed below involves verbs with infinitival complements that take an object NP (typically but not only in the form of a prepositionally marked pronoun). These $\mathbf{V}$-inf object $\mathbf{V}$-inf strings correspond to English let him go $\sim$ allow him to go; make him go $\sim$ force him to go; have him go cause him to go; forbid him to go, ask him to go. In our Hebrew data-base, such constructions included introducing verbs referring to Permission (e.g., ten li 'give to-me = let me', tarše li 'permit to-me', Prohibition (e.g., asur lexa = '(it is) forbidden to-you = you mustn't'); Causation: (e.g., garam lánu 'caused to-us', hevi otánu le- 'brought us to'); and Compulsion: hixriax oto 'forced him', ilec oti 'compelled me'). In the narratives produced by older children, these constructions were analyzed as part of a single clause. However, in analyzing our early (cross-sectional and longitudinal) data-base for toddlers (e.g., Dromi \& Berman, 1986; Lustigman \& Berman, 2016) they were counted as "intermediate" between single and dual-clause constructions. That is, they were viewed as a transitional or "bridge" means of moving into canonic clause-combining. Examples (from our adult) data-base of non-finite clause-combining subordination are given in (9) with "intermediate" type complements compared with adverbial clauses in (10), with a bracket ] indicating the clause boundary.

(9) Complements:

a. bikášti mi-meno ] le-haxzir li 'I asked of-him ] to-return ...' amru le-xulam ] la-azor '(they) told to-everyone ] to-help' ša'álti ] ex le-hagía le-šam 'I asked ] how to-get there'

b. ha-matara šeli hayta ] le-hagia 'my aim was ] to-arrive' ha-xi tov ze] le-nasot šuv 'the best it (= is ] to try again'

The infinitival complements in (9a) typically follow verba dicendi or cognitive verbs of the kind discussed in the preceding paragraph, while in (9b) they function as the complements of copular clauses. The adverbial subordinate clauses in (10) are of different kinds, expressing inter-clausal relations of purpose in (10a), omission (10b), and substitution (10c).

(10) Adverbials:

a. hu miher ] kdey le-hagia bazman 'he hurried ] in order toarrive on time'

b. hu halax ] bli le-hagiv 'without to-react = reacting'

c. hu xiyex ] bimkom le-daber 'he smiled instead of totalk=talking'

Examples of varied types of such infinitival subordinate clauses produced by children aged 5 and 9 years old from the Hebrew "frogstory" narratives (Berman \& Neeman, 1994) are given in (11). 
(11) a. ha-yéled amar la-kélev šelo ] le-hizaher me-ha-dvorim ]

'The-boy told his dog ] to-be-careful of the-bees'

b. ha-yéled ša'al ] efo le-xapes et ha-cfardéa šeli ?]

'The-boy asked ] where to-look for my frog? ]' =

where should I look ...?

c. hem hayu me'ušarim ] la-kaxat ota ha-báyta itam ]

'They were happy ] to-take her [=it] home with them ]'

d. hem lo yad'u ] ma la'asot ] li-mco ota ]

'They didn't know] what to-do ] to-find her ] '

The example in (11d) from a 9-year-old schoolboy strings together two infinitival clauses: the first a complement of the verb 'know', the second a purpose adverbial modifying 'what to-do'. One change with age is that marking of purpose and other types of adverbial clauses becomes lexically more specific, as shown in (12), from "frogstory" accounts of 5-year-olds compared with 9-year-olds.

(12) a. hu tipes al ha'ec ] le-xapes et ha-cfardéa ]

'he climbed up the tree] to-look-for the frog'

b. hu tipes al ha'ec ] kdey-lexapes et ha-cfardéa ]

'he climbed up the tree] so as to-look-for the frog'

c. hu tipes al ha'ec ] al mnat-lexapes et ha-cfardéa ]

'he climbed up the tree] in-order to-look-for the frog'

In sum, nonfinite subordination - indicative of relatively advanced language use - occurred from preschool school age, as young as age 3 years. Developmentally, complement clauses, which are relatively paratactic, stringing rather than subordinating constructions, occur earlier than hypotactic adverbial clauses (Berman and Nir, 2009). Moreover, the latter become lexically more specific with age (as shown in (12). ${ }^{12}$

4.2.3. Paratactic clause-combining by coordination. Early narrative productions of young children, in Hebrew as in other languages, are marked by a juvenile stringing of finite clauses by coordination as a means of adding new events to the narration (Berman, 1996). This is shown by the example of an excerpt in (13) from a (17-clause) story told by a girl aged 3;5, asked to tell about a fight or quarrel she had experienced are - with clause-endings marked by a bracket $]$ and adult input in curly brackets $\{\ldots\}$.

(13) (i). Yael baxta J aval loh asiti la shum davar. ] hi hipila oti ] ve natnu la óšonesh. ] Nili natna la óonesh ] ve hi baxta.] \{kaxa ze nigmar?\}

'Yael cried] but I didn't do anything]. She threw me down] and (they) punished me ]. Nili punished me ] and she cried]. \{That's how it ended\}

12 Non-finite relative clauses are rare in Hebrew, and hardly ever occur in child language. 
(ii). ve Bar hipila al ha-ecba et hakubiya kaxa ] (SHOWS) ve ze kaav li. ]

\{hišlamtem basof?\}

'And Bar threw a block on my finger like that ] (Demonstrates) and it hurt.] '

\{Did you make up in the end?\}

(iii) ve asinu šólem šólem le'olam ve banana ve banana kilogram. ]

'And we did friends, friends for-ever, and banana banana kilogram' (children's formula for making up after a quarrel, šólem stands for shalóm 'peace')

This type of coordination stringing is even more marked in children's picture-book based narratives, marking page-by-page sequentiality of events by combining ve- 'and' with az 'then', axar kax 'after that'. This is shown in the "frogstory" excerpts in (14) - from a girl aged 3;5 - and (15) from a 4-year-old boy.

(14) po ha-yeled yošev

ve ha-cfardea ... yoševet, ve ... az ha-cfardea yocet. ve po ha-kelev nitka benatayim,
Here the-boy sits

and the-frog ... er sits:FEM, and $\ldots$ then the-frog exits:FEM.

And here the-dog is.stuck meanwhile,

ve hu merim et ha-magaf gavoa. and he raises ACC the-boot high. ve hu mexabek oto

And he hugs him

The following excerpt in (15) - translated directly into English -- from a child one year older than the girl in (14) uses more explicit means for denoting picture-by-picture (rather than story-event linked) sequences.

(15) So he saw ] and afterwards the frog went out]. Afterwards the dog went inside the frog's jar ] and he was mad at home.] He fell, the dog. ] Afterwards, he called for the frog ] and then he - he climbed the tree. ] And afterwards he fell from the tree ] ...

Earlier studies have pointed to the fact that that Hebrew speaker-writers tend to rely heavily on coordination as a favored means of clause-combining complex syntax, in keeping with the tendency to parataxis in classical Biblical Hebrew and other Semitic languages (Nir \& Berman, 2010). A major finding of the present study is that this typological feature is reflected in the usage of Hebrew-speaking children as well - as shown by the examples in (16) by 9 -year-old grade-school students, asked to give a talk on the topic of "problems at school".

(16) a. ha-more carix la-azor lo ] ve le-hasbir lo ] ...

'the-teacher must to-help him ] and to explain to-him'

b. ha-more asur lo licok al yeladim ] ve le-... le-haxzik otam ]

'the-teacher mustn't to-yell at kids ] and to ... hold them] 
ve la-káxat otam la-mnahel ] ...

and to-take them to-the-principal'

The examples in (16a) and (16b) show non-finite coordination with the basic additive coordinating conjunction ve- 'and' (Berman, 1996), as a means of combining two or three clauses together. The more extended excerpt in (17), from another 9-year-old, shows a more varied, less repetitive type of paratactic clause-combining.

(17) (i). asur le-ha'atik eh yeled mi-yeled ] '(it's) forbidden (= you mustn't) to copy from one kid to the other

(ii). gam lo la-tet le-ha'atik ]

(iii). lo la-xlom be-mivxanim ]

(iv). éla la'asot et ze ... ]

(v). keilu ata ose mivxan ] 'also not to-allow to-copy

'not to-dream in-tests

'but to-do it $[=\mathrm{Gm}$. sondern]

'as-if you are-doing (a) test'

The excerpt in (17) is a longer and more varied example of clausecombining by coordination of four different clauses. These are introduced by a main clause in the form of a present-tense copular clause with a modal + infinitival complement in (17-i), with the last clause in the generic present in (17-v). Instead of the repetitive, basic ve- 'and', this boy strings his clauses together either by using the additive particle gam 'also, too, as well' in (17-iii) and the sophisticated adversative éla 'but' in the sense of German sondern rather than the basic adversative conjunction aval 'but' in (17-iv).

Nonfinite coordination as a means of discourse connectivity. Stringing of coordinate clauses of the kind illustrated in (17) above is a widely accepted means of creating discourse connectivity in maturely proficient Hebrew. This is illustrated by the excerpts in (18) and (19) - divided into clauses - from talks given by two adult university graduate students on the topic of interpersonal conflict.

(18) (i). meod meod xašuv le-lamed otanu

'(it is) very very important to-teach us

(ii). ve-gam kol exad be'ecem li-lmod be'acmo

'and also(for) each one in-fact to-learn by-himself

(iii). le-hakšiv la-xaver šelo,

'to-listen to-his comrade,

(iv). le-nasot la-x̌̌ov ex ha-xaver xošev,

'to-try to-think how the next one thinks,

(v). le-nasot le-havin me-efo hu magia,

'to-try to-understand where he's coming from, 
(vi). ve-az ulay le-hacliax le-šader be-oto gal,

'and-then maybe to-manage to-communicate on the same wavelength

(vii). ve-limnoa hamon beayot benenu. 'and to-prevent lots-of problems between-us'.

In (18), the speaker coordinates no fewer than seven clauses in a single "syntactic package" (Berman \& Slobin, 1994). She marks this relation by clause-initial ve-gam 'and also', ve-az 'and then' in (18-ii) and (18-vi), and concludes with a clause-initial ve- 'and' in (18-vii). The intermediate clauses are strung together without overt marking in (18iii) to $(18 \mathrm{v})$, with a repeated clause-internal trigger le-nasot 'to-try to ...' in (18-iv) and (18-v). Together, this narrative chunk shows a deft alternation between repetitive parallelism and lexico-syntactic variation. The excerpt in (19) from another graduate student talking about "problems between people" is an even more extreme example of stringing one infinitival clause after another without overt syntactic marking.

(19) beayot ben bney adam nov'ot mi-sibot šonot

'problems between people come from varied reasons

ve mi-écem tivo šel ha-adam

'and from the very nature of man

$\begin{array}{ll}\text { la-riv } & \text { 'to-quarrel } \\ \text { le-hitvakeax } & \text { 'to-argue } \\ \text { le-hitpalmes } & \text { 'to-dispute } \\ \text { le-hitxašben } & \text { 'to-keep accounts } \\ \text { ve lekane } & \text { 'and to-envy' }\end{array}$

The excerpts in (18) and (19) reflect two important typological features of Hebrew, like other Semitic languages. One is the propensity for expressing relations of semantic and syntactic equivalence or symmetry - in this case by partial or total repetition of lexical material and stringing of equivalent syntactic constructions (Jakobson, 1960; Nir \& Berman, 2010; Reinhart, 1984). Second, mature Hebrew speakers (and writers) reflect this tendency by means of paratactic constructions - in the case at issue here, of non-finite coordinated clauses. This classical type of construction serves a major role in text-embedded discourse connectivity.

Finally, Hebrew also allows for hypotactic subordination of nonfinite clauses, as in the excerpt in (20) below, also from an adult's talk on interpersonal conflict.

(20) (i). ata carix o le-hitnacel

'you must [=need] or [=either] to-apologize

(ii). o la-x̌šov

'or to-think 
(iii). ex la-asot et ze ba-atid

'how to-do it in future

(iv). kdey le-šaper et ha-txuša šelxa

'so-as to-improve your feeling'

In (20), the speaker uses a more complex type of coordination, expressing alternativeness by the correlative $o \ldots$ o 'either ...or' tightly linking (20i) and (20ii), which are then followed by a question-complement clause in (20iii) and an adverbial of purpose in (20iv). The device of linking similar syntactic structures by equivalent coordination as in (18) and (19), rather than by dependent subordination as in (20), appears structurally straightforward. Yet it takes until well into school-age and adolescence for speaker-writers to achieve either of these levels of textual cohesion.

\section{Summary and Discussion}

The aim of this study was to track the developmental journey of a single linguistic subsystem or set of forms - here, infinitives in acquisition of Hebrew as L1. However, in order to adequately account for development, in language as in other cognitive domains, and to meet the cognitive and discursive demands of "integration" of systems and "re-representation" of knowledge (Karmiloff-Smith, 1985, 1995) a given set of forms cannot be adequately accounted for in isolation. In the case at point here, use of infinitives in Hebrew needs to be compared with use of subordinate clauses and of other non-finite verb forms as a means of textual connectivity, on the onehand, and of nominalizations as an even denser means for organizing predicating information (Ravid \& Cahana-Amitay, 2005). Moreover, in order to assess the impact of target-language typology, the use of a linguistic system such as infinitives in Hebrew needs to be compared with corresponding constructions in other languages as well.

The study presented here illustrates in Hebrew-specific terms the lengthy developmental path of L1 language acquisition from emergence to proficiency, as demonstrated earlier for narrative construction in Berman \& Slobin (1994) and for various Hebrew-language constructions in Berman (2004a). The developmental trajectory of Hebrew infinitival structure and use was traced from initial, unmarked "bare stems" via le-prefixed forms used as a juvenile means for expressing Imperative mood (requests, demands) to "extended predicates" as the major means of elaborating on predicate verbs in a language lacking in auxiliaries,. These pre-school age abilities were shown to be followed by to stringing and coordinating infinitival constructions as a means of clause-combining complex syntax leading up to elaborate syntactic clausepackaging as a favored device for expressing discursive connectivity.

A question arises regarding use of the term "pre-grammatical" in relation to non-affixed "bare stems" (Section 4.1.1). On the one hand, these forms are 
strictly juvenile and do not occur as such in adult input language. On the other hand, they are morpho-phonologically native-like since (i) they take the form of possible syllables in Hebrew, and (ii) they show traces of the morphological binyan pattern or prosodic template of the target verbs they represent (Adam \& Bat-El, 2008; Berman \& Armon-Lotem, 1997; Lustigman, 2012). This combines the dual nature of children's early speech. On the one hand, it often reflects juvenile forms that are transient, since they do not occur in adult usage (Berman, 1981; Ravid, 1995); but on the other, it from very early on reflects the impact of target language typology as typically, say, Hebrew, English, Korean, or Turkish (Bowerman, 2011; Slobin, 1996; Slobin, Bowerman, Brown, Eisenbeiss \& Narasimhan, 2011).

The impact of typology is interpreted here as reflecting the combination of three main factors: (i) grammar - the properties and constraints of the morphosyntactic structures of a particular language; (ii) affordances - the repertoire of expressive options in lexicon and grammar available to speakers of that language; and (iii) usage - the most frequent and rhetorically favored means of expression occurring in the ambient language. In the domain of infinitives, the impact of typology is manifested in Hebrew-speaking children's early reliance on extended predicates as a means of verb-phrase elaboration, followed by stringing and coordination of paratactic infinitival, non-finite constructions. In this, children's language, and that of contemporary Hebrew usage in general (Nir \& Berman, 2010), reflects the classical Biblical favoring of parallel constructions and of paratactic means of combining predications (Goldfain, 1998; Polak, 1998; Rubinstein, 1980; Waltke \& O'Connor, 1990) typical of Semitic languages (for Arabic, for example, see Johnston, 1987; Ostler, 1987, 1988).

Third, language development is a protracted process, in which different systems evolve in tandem. For example, in the present context, the syntactic complexity of the environments in which infinitives occur increases in depth of contingency (from use in isolation to clause-internal extended predicates to pair-wise clause-combining and lengthy discursive packaging). Increased structural complexity also reveals development in the functions of infinitives: From a childish means of communicating requests and demands to verbphrase expansion, and on to discursive topic-maintenance by repeated use of a subjectless non-finite structure. Concurrently, lexical development is revealed by the modal and aspectual operators that trigger infinitives in extended predicates, as more varied and of higher register - compare the juvenile examples in (5) with adult usages in (6) and (7). And semantically, the markers of (nonfinite) subordinate clauses shiftfrom childish gam 'also', to generic ve- 'and' on to adversatives and correlative conjoining.

These findings point to two major factors that interact with target language typology in explaining the trajectory of language development across children and languages. It reveals both shared socio-cognitive developments in the ability to process and combine increasingly complex chunks of discourse 
on-line (Tomasello, 2009) and the experiential impact of growing linguistic literacy (Ravid \& Tolchinsky, 2002), in the form of greater exposure to a wider range of more varied types of language and the ability to produce tightly packaged extended texts.

As for desiderata: The aim of this study was to track the developmental journey of a single linguistic subsystem or set of forms - here, infinitives in acquisition of Hebrew as L1. However, in order to adequately account for development, in language as in other cognitive domains, in order to meet the cognitive and discursive demands of what Karmiloff-Smith $(1985,1995)$ terms "integration" of systems and "re-representation" of knowledge, a given set of forms cannot be adequately accounted for in isolation. Thus use of infinitives in Hebrew needs to be compared with use of subordinate clauses and of other non-finite verb forms as a means of textual connectivity as well as with nominalizations as a means of even denser organization of predicating information (Ravid \& Cahana-Amitay, 2005). And in examining the impact of target-language typology, use of infinitives in Hebrew needs to be compared with corresponding constructions in other languages as well.

\section{References}

Adam, G., \& Bat-El, O. (2008). Morphological knowledge without morphological structure. Current Issues in Generative Hebrew Linguistics, 134, 197.

Azar, M. (1977). Surface and depth in syntax. Haifa: Haifa University Press [in Hebrew].

Berman, R. A. (1978a). Modern Hebrew structure. Tel Aviv: University Publishing Projects.

Berman, R. A. (1978b). Early verbs: How and why a child uses her first words. International Journal of Psycholinguistics, 5, 21-29.

Berman, R. A. (1980). On the category of auxiliary in Modern Hebrew. Hebrew Annual Review, 4, 15-37.

Berman, R. A. (1981). Language development and language knowledge: Evidence from the acquisition of Hebrew morphophonology. Journal of Child Language, 8(3), 609-626.

Berman, R. A. (1985). Acquisition of Hebrew. Hillsdale, NJ: Lawrence Erlbaum. [Also in D. I. Slobin (Ed.), Crosslinguistic study of language acquisition, (vol. I, pp. 255-371). Hillsdale, NJ: Lawrence Erlbaum]

Berman, R. A. (1986). A step-by-step model of language learning. In I. Levin (Ed.), Stage and structure: Re-opening the debate (pp. 191-219). Norwood, NJ: Ablex.

Berman, R. A. (1988). On the ability to relate events in narratives. Discourse Processes, 11, 469-97. 
Berman, R. A. (1993). Developmental perspectives on transitivity: A confluence of cues. In Y. Levy (Ed.), Other children, other languages: Issues in the Theory of Acquisition (pp. 189-241). Hillsdale, NJ: Lawrence Erlbaum.

Berman, R. A. (1996). Form and function in developing narrative abilities: The case of 'and'. In D. Slobin, J. Gerhardt, A. Kyratzis, \& J. Guo (Eds.), Social interaction, context, and language: Essays in honor of Susan Ervin-Tripp (pp. 343-367). Mahwah, NJ: Lawrence Erlbaum.

Berman, R. A. (2001). Setting the narrative scene: How children begin to tell a story. In A. Aksu-Koç, C. Johnson, \& K. Nelson (Eds.), Children's language (vol. 10, pp. 1-31). Mahwah, NJ: Lawrence Erlbaum.

Berman, R. A. (2004a). Between emergence and mastery: The long developmental route of language acquisition. In R. A. Berman (Ed.), Language development across childhood and adolescence (Trends in language acquisition research [TILAR]) (vol. 3, pp. 9-34). Amsterdam: John Benjamins.

Berman, R. A. (2004b). The role of context in developing narrative abilities. In S. Strömqvist \& L. Verhoeven (Eds.), Relating events in narrative: Typological and contextual perspectives (pp. 261-280). Mahwah, NJ: Lawrence Erlbaum.

Berman, R. A. (2008). The psycholinguistics of developing text construction. Journal of Child Language, 35, 735-771.

Berman, R. A. (2014). Acquiring and expressing temporality in Hebrew: A T/ (M/A) Language. SKASE Journal of Theoretical Linguistics, 11(2), 2-29.

Berman, R. A. (2017). Usage-based perspectives on form-function relations: The case of nonfinite verbs in Modern Hebrew. Keynote talk, 3rd Usage-Based Linguistics Conference, Hebrew University, Jerusalem, July.

Berman, R. A \& Armon-Lotem, S. (1997). How grammatical are early verbs? In C. Martinot (Ed.), Annales littéraires de l'Université de Franche-Comté: Actes du colloque international sur l'acquisition de la syntaxe (pp. 17-60).

Berman, R. A. \& Neeman, Y. (1994). Development of linguistic forms: Hebrew. In R. A. Berman \& D. I. Slobin (Eds.), Relating events in narrative: A crosslinguistic developmental study (pp. 285-328). Hillsdale: Lawrence Erlbaum.

Berman, R. A. \& Nir-Sagiv, B. (2009). Clause-packaging in narratives: A crosslinguistic developmental study. In J. Guo, E. Lieven, N. Budwig, S. Ervin-Tripp, K. Nakamura, \& S. Ozcaliskan (Eds.), Crosslinguistic approaches to the psychology of language: Research in the tradition of Dan I. Slobin (pp. 149-162). New Zork, NY: Taylor \& Francis.

Berman, R.A. \& Slobin, D. I. (1994). Relating events in narrative: A crosslinguistic developmental study. Hillsdale, NJ: Lawrence Erlbaum.

Berman, R. A. \& Verhoeven, L. (2002). Developing text production abilities in speech and writing: Aims and methodology. Written Languages and Literacy, $5,1-44$.

Blau, J. (1966). Essentials of syntax. Jerusalem: Israel Institute for Writing Education [in Hebrew]. 
Bloom, L., Tackeff, J., \& Lahey, M. (1984). Learning to in complement constructions. Journal of Child Language, 11(2), 391-406. http://dx.doi. org/10.7916/D8P84C4V

Bowerman, M. (2011). Linguistic typology and first language acquisition. In J. J. Song (Ed.), The Oxford handbook of linguistic typology (pp. 591-617). Oxford: Oxford University Press.

de Villiers, J. G., \& de Villiers, P. A. (1986). The acquisition of English. The Crosslinguistic Study of Language Acquisition, 1, 27-139.

Dekel, N. (2010). A matter of time: tense, mood and aspect in spontaneous Spoken Israeli Hebrew. Netherlands Graduate School of Linguistics.

Diessel, H. (2004). The acquisition of complex sentences (Vol. 105). Cambridge: University Press.

Dromi, E. \& Berman, R. A. (1986). Language-general and language-specific in developing syntax. Journal of Child Language, 14, 371-387.

Dubnov, K. (2015). Circumstantial versus depictive secondary predicates in literary Hebrew - the influence of Yiddish and Russian. In E. Doron (Ed.), Language contact and the development of Modern Hebrew (pp. 77-86). Leiden: Brill.

Evans, N. (2007). Insubordination and its uses. In I. Nikolaeva (Ed.). Finiteness: Theoretical and empirical foundations (pp. 367-431). Oxford: Oxford University Press.

Evans, N., \& Watanabe, H. (Eds.). (2016). Dynamics of insubordination. Amsterdam: John Benjamins Publishing Company.

Faust, N. (submitted). Gutturals in Modern Hebrew. To appear in R. A. Berman \& E. Grossman (Eds.), A usage based reference grammar of Modern Hebrew. Berlin: Mouton De-Gruyter.

Givón, T. (2009). The genesis of syntactic complexity. Amsterdam: John Benjamins.

Goldfajn, T. (1998). Word order and time in Biblical Hebrew narrative. Oxford: Clarendon Press.

Jakobson, R. (1960). Closing statement: Linguistics and poetics. In T. A. Sebeok (Ed.), Style in language (pp. 350-377). Cambridge, MA: MIT Press.

Johnstone, B. (1987). Parataxis in Arabic: Modification as a model for persuasion. Studies in Language, 11, 85-98.

Kalev, D. (2017a). Modern times-tenses: Grammaticization of the anterior in contemporary Hebrew. In A. Amit \& H. B. Z. Shyldkrot (Eds.), Proceedings of the 29th and 30th Annual Conferences of the Israel Linguistic Society, 20, 51-60.[In Hebrew]

Kalev, D. (2017b). Relative tenses in Hebrew: Anterior and posterior. In A. Amit \& H. B. Z. Shyldkrot (Eds.), Proceedings of the 31st and 32nd Annual Conferences of the Israel Linguistic Society, 21, 20-40. [In Hebrew]

Kaplan, D. \& Berman, R. A. (2015). Developing linguistic flexibility across the school years. First Language, 35, 27-53. 
Karmiloff-smith A. (1985). Language and cognitive processes from a developmental perspective. Language and Cognitive Processes, 1, 61-85. DOI: $10.1080 / 01690968508402071$

Karmiloff-Smith, A. (1995). Beyond modularity: A developmental perspective on cognitive science. Cambridge, MA: MIT press.

Lustigman, L. (2012). Non-finiteness in early Hebrew verbs. Brill's Annual of Afroasiatic Languages and Linguistics (BAALL), 4, 213-231.

Lustigman, L. (2013). Developing structural specification: Productivity in early Hebrew verb usage. First Language, 33, 47-67.

Lustigman, L. (2015). Optional opacity: A syntactically-based analysis of early Hebrew verb morphology. First Language, 35, 466-488.

Lustigman, L. (2016a). From opacity to transparency: Transitional categories in early Hebrew grammar. In R. A. Berman (Ed.), Acquisition and Development of Hebrew: From infancy to adolescence (Trends in Language Acquisition Research [TILAR]) (vol. 19, pp. 225-258). Amsterdam: John Benjamins.

Lustigman, L. (2016b). Interfaces between linguistic systems: Evidence from child language. Linguistics, 54, 273-303.

Lustigman L. \& Berman, R. A. (2016). Form and function in early clausecombining. Journal of Child Language, 43, 157-185.

Nir-Sagiv, B. \& Berman, R. A. (2010). Complex syntax as a window on contrastive rhetoric. Journal of Pragmatics, 42, 744-765.

Ostler, Shirley E., 1987. English in parallels: A comparison of English and Arabic prose. In: Connor, U. \& Kaplan, R. (Eds.), Writing across languages: Analysis of L2 texts (pp. 169-185). Reading, MA: Addison Wesley.

Ostler, S. E. (1988). A study in the contrastive rhetoric of Arabic, English, Japanese, and Spanish. Doctoral Dissertation. University of Southern California.

Polak, F. H. (1998). The oral and the written: Syntax, stylistics and the development of Biblical prose narrative. Journal of the Ancient Near Eastern Society, 26, 59-105.

Ravid, D. (1995). Language change in child and adult Hebrew: A psycholinguistic perspective. Oxford: Oxford University Press.

Ravid, D. (2003). A developmental perspective on root perception in Hebrew and Palestinian Arabic. Language Acquisition and Language Disorders, 28, 293-320.

Ravid, D., Ashkenazi, O., Levie, R., Ben Zadok, G., Grunwald, T., Bratslavsky, R. \& Gillis, S. (2016). Foundations of the root category: analyses of linguistic input to Hebrew-speaking children. In R. A. Berman (Ed.), Acquisition and Development of Hebrew: From Infancy to Adolescence (Trends in Language Acquisition Research [TILAR]) (vol. 19, pp. 95-134). Amsterdam: John Benjamins.

Ravid, D. \& Cahana-Amitay, D. (2005). Verbal and nominal expression in narrating conflict situations in Hebrew. Journal of Pragmatics, 37, 157-183. 
Ravid, D. \& Tolchinsky, L. (2002). Developing linguistic literacy: A comprehensive model. Journal of Child Language, 29, 419-448.

Reilly, J. S., Jisa, H., Baruch, E. \& Berman, R. A. (2002). Modal expression of propositional attitudes. Written Languages and Literacy, 5(2), 183-218.

Reinhart, T. (1984). Principles of gestalt perception in the temporal organization of narrative texts. Linguistics, 22(6), 779-810.

Rubinstein, E. (1980). Contemporary Hebrew and Ancient Hebrew. Tel Aviv: University on the Air [in Hebrew].

Schwarzwald, O. (2003). Opacity in Hebrew word morphology. In J. Shimron (Ed.), Language processing and acquisition in languages of Semitic, rootbased, morphology (pp. 147-163). Amsterdam: John Benjamins.

Seroussi, B. (2014). Root transparency and the morphology-meaning interface: Data from Hebrew. In F. Rainer, F. Gardani, H. C. Luschützky, \& W. U. Dressler (Eds.), Morphology and Meaning [Current Issues in Linguistic Theory 327$]$ (pp. 289-301). Amsterdam: John Benjamins.

Slobin, D. I. (1996). From "thought and language" to "thinking to speaking". In J. J. Gumperz \& S. C. Levinson (Eds.), Rethinking linguistic relativity (pp. 70-96). Cambridge: Cambridge University Press.

Slobin, D. I. (2004). The many ways to search for a frog. In S. Strömqvist \& L. Verhoeven (Eds.), Relating events in narrative: Typological and contextual perspectives (vol 2, pp. 219-257). Mahwah, NJ: Lawrence Erlbaum.

Slobin, D. I., Bowerman, M., Brown, P., Eisenbeiss, S. \& Narasimhan, B. (2011). Putting things in places: Developmental consequences of linguistic typology. In J. Bohnemeyer \& E. Pederson (Eds.), Event representation in language and cognition (pp. 134-165). New York, NY: Cambridge University Press.

Tomasello, M. (2009). Constructing a language. Cambridge, MA: Harvard University Press.

Waltke, B. K., \& O'Connor, M. P. (1990). An introduction to Biblical Hebrew syntax. Winona Lake, Ind: Eisenbrauns. 